\title{
Verrucosispora gifhornensis gen. nov., sp. nov., a new member of the actinobacterial family Micromonosporaceae
}

\author{
Holger Rheims, ${ }^{1}$ Peter Schumann, ${ }^{1}$ Manfred Rohde ${ }^{2}$ \\ and Erko Stackebrandt ${ }^{1}$ \\ Author for correspondence: Erko Stackebrandt. Tel: +495312616 352. Fax: +495312616418. \\ e-mail: erko@gbf.de
}

DSMZ-Deutsche Sammlung von Mikroorganismen und Zellkulturen ${ }^{1}$ and GBF-Gesellschaft für Biotechnologische Forschung $\mathrm{GmbH}$, Bereich Mikrobiologie2, D-38124 Braunschweig, Germany
A Gram-positive, aerobic, spore-forming actinomycete strain, $\mathrm{HR}^{2} \mathbf{2}^{\top}$, was isolated from a peat bog near Gifhorn, Lower Saxony, Germany. Comparative analysis of the $165 \mathrm{rDNA}$ sequence indicated that $\mathrm{HR} 1-2^{\top}$ was phylogenetically related to members of the family Micromonosporaceae, branching adjacent to Spirilliplanes yamanashiensis, Couchioplanes caeruleus, Catenuloplanes japonicus and members of the genus Micromonospora. The affiliation to the family was supported by the presence of family-specific 165 rDNA signature nucleotides, DNA G+C content of $70 \mathrm{~mol} \%$, peptidoglycan of type A1 $\gamma^{\prime}$ (directly crossed-linked, presence of glycine, alanine, glutamic acid and mesodiaminopimelic acid in the peptide side-chain), menaquinone $M K-9\left(H_{4}\right)$ as the major respiratory lipoquinone, polar lipid composition PII (phosphatidylethanolamine, diphosphatidylglycerol, phosphatidylserine and phosphatidylinositolmannosides) and a glycolyl type of muramic acid. It differed from genera of the family by the lack of arabinose in whole-cell sugars and a unique nucleotide signature stretch between positions 1132 and 1143 (Escherichia coli numbering), 5' CAAUUCGGUUG 3'. Morphologically strain HR1-2 ${ }^{\top}$ resembles Micromonospora species but can be distinguished from them by the lack of arabinose in whole-cell sugars, the presence of 10-methyl $C_{17: 0}$ fatty acids and a distinct 165 rDNA sequence. Based on the unique combination of morphological, chemotaxonomic and phylogenetic properties a new genus, Verrucosispora gen. nov., is proposed. The type species of this genus is Verrucosispora gifhornensis sp. nov., and the type strain of $V$. gifhornensis is strain HR1-2' ${ }^{\top}$ ( = DSM 44337').

Keywords: Verrucosispora gifhornensis, Micromonosporaceae, 16S rDNA analysis, phylogeny, chemotaxonomy

\section{INTRODUCTION}

The family Micromonosporaceae has recently been placed in the suborder Microsporineae as one of several suborders of the order Actinomycetales, subclass Actinobacteridae, class Actinobacteria (Stackebrandt et al., 1997). The recognition as a suborder was based on the distinct phylogenetic position of members of the family as determined by $16 \mathrm{~S}$ rDNA analysis as well as the presence of a family-specific pattern of 16S rDNA nucleotides which distinguished its members from all

The EMBL accession number for the 16S rDNA sequence of strain HR1-2 ${ }^{\top}$ is $Y 15523$. other actinomycete species. The family comprises the genera Micromonospora, Actinoplanes, Catellatospora, Catenuloplanes, Couchioplanes, Dactylosporangium and Pilimelia (Koch et al., 1996a) and the recently described genus Spirilliplanes (Tamura et al., 1997).

Although most of these genera are phylogenetically closely related (Koch et al., 1996a; Tamura et al., 1997), members of the genera can be distinguished by morphological features such as the presence or absence of sporangia, spore motility, chemotaxonomic properties including fatty acid profiles, chemical composition of cell wall and whole cells and phospholipid types. The decision whether a new isolate should be affiliated to one of the established genera or whether it represents 
a novel genus must therefore take into account the phylogenetic position and the combination of phenotypic properties. In this paper we describe the characteristics and the resulting classification of strain HR1$2^{\mathrm{T}}$ ( $\mathrm{T}=$ type strain). On the basis of a unique combination of genotypic and phenotypic characteristics we propose that this organism is placed in a new genus and species of the family Micromonosporaceae designated Verrucosispora gifhornensis.

\section{METHODS}

Bacterial strains and cultural conditions. Strain HR $1-2^{\mathrm{T}}$ was isolated from a peat sample taken in October 1995 from a peat bog near Gifhorn, Lower Saxony, Germany $\left(10^{\circ} 33^{\prime} \mathrm{E}\right.$, $\left.52^{\circ} 30^{\prime} \mathrm{N}\right)$. Samples were taken from a depth of $20-40 \mathrm{~cm}$ after removal of the top peat layer. Ten grams of an aged peat sample, stored at $4{ }^{\circ} \mathrm{C}$ for 12 months, were suspended in a flask with sterile tap water to a final volume of $100 \mathrm{ml}$. Ten millilitres of this suspension was added to another $90 \mathrm{ml}$ of sterile tap water which was repeated to set up a tenfold dilution series to $10^{-6}$. Of the final dilution step, aliquots of $200 \mu \mathrm{l}$ were spread-plated onto Actinomycete isolation agar, pH 8.2 (Difco), prepared without the addition of glycerol. Following sterilization of the medium, the antibiotics cycloheximide and nystatin were added to a final concentration of $100 \mu \mathrm{g} \mathrm{ml}^{-1}$ each. After $11 \mathrm{~d}$ aerobic incubation at $30^{\circ} \mathrm{C}$, growth of isolate HR1-2" was indicated by an expanding clear circular zone in the medium. Further incubation for another $17 \mathrm{~d}$ allowed development of an orange-red colony which was transferred to fresh Actinomycete isolation agar. Incubation was for $14 \mathrm{~d}$ until a well-developed mycelium occurred on the plate and purity of the isolate could be confirmed.

Short-term storage was carried out by inoculating $5 \mathrm{ml}$ tryptic soy broth (Difco), with the addition of $3.0 \mathrm{~g} \mathrm{l}^{-1}$ yeast extract prior to autoclaving, with a loopful of cell material for $7 \mathrm{~d}$ at $28^{\circ} \mathrm{C}$, shaking. Aliquots of $1 \mathrm{ml}$ of the suspension were thoroughly mixed with $1 \mathrm{ml}$ glycerol and immediately frozen at $-70^{\circ} \mathrm{C}$. Long-term storage was carried out at the DSMZ by freeze-drying and storage in liquid nitrogen.

The organisms used for comparison of the physiological and chemotaxonomic properties were: Spirilliplanes yamanashiensis IFO $15828^{\mathrm{T}}$ (= DSM 44325 ) (Tamura et al., 1997) and Micromonospora olivasterospora DSM $43868^{\circ}$ (Kawamoto et al., 1983).

Determination of physiological characteristics. A pre-culture of isolate HR $1-2^{\mathrm{T}}$ was grown in tryptic soy broth with yeast extract at $28^{\circ} \mathrm{C}$ for $7 \mathrm{~d}$. One millilitre of the cell suspension was pelleted by centrifugation. The pellet was washed twice by resuspension and centrifugation in mineral base medium (Stanier et al., 1966) and finally suspended in $10 \mathrm{ml}$ of this medium. Aliquots of $100 \mu \mathrm{l}$ of this solution were taken to inoculate the following physiological tests.

The temperature and $\mathrm{pH}$ ranges for the growth of isolate HR $1-2^{\mathrm{T}}$ were determined in tryptic soy broth with yeast extract. Temperature range tested was from 8 to $60^{\circ} \mathrm{C} ; \mathrm{pH}$ range tested was from $3 \cdot 0$ to $8 \cdot 5$. Carbon source utilization was tested at $35^{\circ} \mathrm{C}$ in standard mineral base medium (Stanier et al., 1966) containing $0.2 \%$ of the carbon source. The tests were set up daily and allowed to grow for 18 and $15 \mathrm{~d}$, respectively, until no further growth in the test tubes was observed.

Growth was also tested on the International Streptomyces Project (ISP) media \#1-\#7 (Shirling \& Gottlieb, 1966) at $35^{\circ} \mathrm{C}$. The utilization of amino acids as nitrogen source was tested as described by Collins et al. (1989). Halotolerance was tested by the use of tryptic soy broth (prepared as described above) with the addition of $0,1,2,3,4,5,7$ and $10 \% \mathrm{NaCl}$, respectively.

Gelatin liquefaction was tested according to the methods of Gerhardt et al. (1981) in that plates of tryptic soy broth (prepared as described above) containing $0.4 \%$ gelatin were incubated with strain HR1-2 $2^{\mathrm{T}}$ for $14 \mathrm{~d}$. For the evaluation the plates were flooded with warm $\left(55^{\circ} \mathrm{C}\right) 1 \mathrm{M}$ sulfuric acid, saturated with $\mathrm{Na}_{2} \mathrm{SO}_{4}$. A resulting clear circular zone around the colony indicates digestion of the gelatin.

Peptonization of milk, starch hydrolysis and nitrite production were tested by procedures described by Gordon et al. (1973). Cellulose decomposition was tested by the use of two-layer agar plates incubated for 2 weeks. The bottom layer contained the growth medium (tryptic soy broth, prepared as described above), while the top layer consisted of $1.5 \%$ water-agar with $0.6 \%$ CM-cellulose. Decomposition of the cellulose is indicated by the formation of clear zones around the colonies.

Growth in the presence of different antibiotics was tested according to the procedure of DIN 58940 (Anonymous, 1991). A pre-culture grown for $2 \mathrm{~d}$ in tryptic soy broth was streaked out on plates of Müller-Hinton Agar (Oxoid). Disks containing the different antibiotics (Susceptibility discs, Oxoid) were applied to the plates with a Disk Dispenser (Oxoid), incubated for $4 \mathrm{~d}$ at $35^{\circ} \mathrm{C}$ and the resulting inhibition zones measured.

To determine whether isolate HR $1-2^{\mathrm{T}}$ produces antibiotic substances, a selection of reference strains was streaked out against the isolate. Reference strains were Escherichia coli DSM 498, Saccharomyces cerevisiae DSM 70449 ${ }^{\mathrm{T}}$, Streptomyces hygroscopicus DSM 40632, Lactobacillus plantarum DSM 20174 ${ }^{\mathrm{T}}$, Enterobacter cloacae DSM 30054 ${ }^{\mathrm{T}}$ and Staphylococcus aureus subsp. aureus DSM $20231^{\mathrm{T}}$. With an inoculation loop a $1 \mathrm{~cm}$ broad line of strain $\mathrm{HR} 1-2^{\mathrm{T}}$ was streaked along the diameter of an agar plate of tryptic soy broth with yeast extract and grown for $5 \mathrm{~d}$ at $35^{\circ} \mathrm{C}$. The reference strains were then streaked out perpendicular to strain HR $1-2^{\mathrm{T}}$, as close as $0.5 \mathrm{~cm}$. Further incubation was at $28^{\circ} \mathrm{C}$ for $8 \mathrm{~d}$.

Electron microscopy. For scanning electron microscopy, agar blocks with cells grown on ISP\#4 were cut out, fixed in $2.5 \%$ $(\mathrm{w} / \mathrm{v})$ glutaraldehyde and dehydrated in a series of increasing acetone concentrations $(10,30,50,70,90$ and $100 \%)$. Preparations were dried at the critical point of liquid $\mathrm{CO}_{2}$, sputter-coated with gold $(10 \mathrm{~nm})$ and examined in a Zeiss model DSM 982 scanning electron microscope.

Analysis of chemotaxonomic characteristics. Cell wall, sugar and lipid analysis were carried out by the methods of Schleifer \& Kandler (1972), Saddler et al. (1991), MacKenzie (1987), Uchida \& Aida (1984), Stead et al. (1992) Collins et al. (1977), Minnikin et al. $(1975,1979)$ and Collins \& Jones (1980), as described previously (Groth et al., 1996).

Isolation of DNA, determination of the $\mathbf{G}+\mathbf{C}$ content and DNA-DNA hybridization. A volume of $300 \mathrm{ml}$ tryptic soy broth was inoculated with isolate $\mathrm{HR} 1-2^{\mathrm{T}}$ and incubated aerobically at $28^{\circ} \mathrm{C}$ until dense growth had occurred. Cells were harvested by centrifugation and disrupted with a French pressure cell. The DNA was purified by chromatography on hydroxyapatite according to the procedure of Cashion et al. (1977). $\mathrm{G}+\mathrm{C}$ contents were determined by 
HPLC (Mesbah et al., 1989). DNA-DNA hybribizations for isolate $\mathrm{HR} 1-2^{\mathrm{T}}$ were carried out by using the thermal renaturation method (DeLey et al., 1970) with modifications as described by $\mathrm{Huß}$ et al. (1983) and Escara \& Hutton (1980) using a Gilford System 2600 spectrophotometer equipped with a Gilford 2527-R thermoprogrammer and plotter. Renaturation rates were computed by the program TRANSFER.BAS (Jahnke, 1992).

PCR amplification of the 16S rRNA gene and sequence analysis. Genomic DNA was extracted by an enzymic lysis procedure and used for PCR-mediated amplification of the 16S rDNA (Rainey et al., 1996). The purified PCR products were directly sequenced by using previously described protocols (Rainey et al., 1996). The sequence reaction mixtures were electrophoresed using a model 373A automatic DNA sequencer (Applied Biosystems).

Phylogenetic analysis. The 16S rDNA sequence of isolate $\mathrm{HR} 1-2^{\mathrm{T}}$ was initially aligned to the sequences of the type species of the class Actinobacteria (Stackebrandt et al., 1997) and subsequently with members of the family Micromonosporaceac (Koch et al., 1996b; Tamura et al., 1997) using the ae2 editor (Maidak et al., 1997). Evolutionary distances were calculated by the method of Jukes \& Cantor (1969). Phylogenetic dendrograms (DeSoete, 1983) were constructed using sequences from different sets of reference strains. Bootstrap analysis was used to evaluate the tree topology of the neighbour-joining data by performing 500 resamplings (Felsenstein, 1985).

\section{RESULTS AND DISCUSSION}

\section{Morphology}

Isolate HR $1-2^{\mathrm{T}}$ produced a well-developed substrate mycelium on all media, approximately $0.4 \mu \mathrm{m}$ in diameter. An aerial mycelium or sporangia were not formed. On older parts (approx. $14 \mathrm{~d}$ ), granular structures on the mycelial surface were observed by scanning electron microscopy. Spores were borne singly from the substrate mycelium having a diameter of $0.8 \mu \mathrm{m}$. The spore surface appeared warty in younger states and changed to a hairy appearance with increased age (Fig. 1). Spores were non-motile.

\section{Physiological characteristics}

Isolate HR $1-2^{\mathrm{T}}$ grew strictly aerobically. On all the media tested orange colonies, which became brownish with increased age, developed. Best growth was observed on agar plates made with tryptic soy broth. No growth was observed below $20^{\circ} \mathrm{C}$ or above $40^{\circ} \mathrm{C}$. Good growth was observed between 30 and $40^{\circ} \mathrm{C}$, with an optimum at $35^{\circ} \mathrm{C}$. The $\mathrm{pH}$ range for growth was from 6.5 to $8 \cdot 2$, with an optimum at $7 \cdot 5$.

Good growth was observed on ISP\# 1 (tryptone-yeast extract broth), ISP\#4 (inorganic salts-starch agar), and ISP\#5 (glycerol-asparagine agar); moderate growth was observed on ISP\#2 (yeast extract-malt extract agar), ISP\#6 (peptone-yeast extract iron agar), and ISP\# 7 (tyrosine agar); no growth was observed on ISP\#3. Growth was slow on HV agar (Hayakawa \& Nonomura, 1987).

Isolate $\mathrm{HR} 1-2^{\mathrm{T}}$ grew well between 0 and $2 \% \mathrm{NaCl}$, moderately between 2 and $4 \%$, but failed to grow above $4 \% \mathrm{NaCl}$.

The results of further physiological tests are summarized in Table 1. Also included are the literature data of the closest phylogenetic relatives to isolate HR $1-2^{\mathrm{T}}$ as judged by $16 \mathrm{~S}$ rDNA analysis.

\section{Antibiotic susceptibility}

Growth of isolate HR $1-2^{\mathrm{T}}$ was strongly inhibited (diameter of the inhibition zone: 31 to $50 \mathrm{~mm}$ ) by amikazin (content per disc: $30 \mu \mathrm{g})$, bacitracin $(10 \mu \mathrm{g})$, cephalozin $(30 \mu \mathrm{g})$, doxycycline $(30 \mu \mathrm{g})$, gentamicin $(10 \mu \mathrm{g})$, imipenem $(10 \mu \mathrm{g})$, kanamycin $(30 \mu \mathrm{g})$, neomycin $(30 \mu \mathrm{g})$, polymyxin $\mathrm{B}(300 \mu \mathrm{g})$ and tetracycline $(30 \mu \mathrm{g})$. Good inhibition $(21-30 \mathrm{~mm})$ was observed with aztreonam $(30 \mu \mathrm{g})$, cefotaxime $(30 \mu \mathrm{g})$, cephalothin $(30 \mu \mathrm{g})$, norfloxacin $(10 \mu \mathrm{g})$, penicillin $\mathrm{G}(6 \mu \mathrm{g})$ and ticarcillin $(75 \mu \mathrm{g})$. Poor inhibition $(10-20 \mathrm{~mm})$ was observed with ampicillin $(10 \mu \mathrm{g})$, azlocillin $(30 \mu \mathrm{g})$, chloramphenicol $(30 \mu \mathrm{g})$, colistin sulfate $(10 \mu \mathrm{g})$, erythromycin $(15 \mu \mathrm{g})$, mezlocillin $(30 \mu \mathrm{g})$ and oflaxacin $(5 \mu \mathrm{g})$. No inhibition was observed with lincomycin $(15 \mu \mathrm{g})$, nitrofurantoin $(100 \mu \mathrm{g})$, oxacillin $(5 \mu \mathrm{g})$ and pipemidic acid $(20 \mu \mathrm{g})$.

\section{Production of antibiotic substances}

As judged by growth of all reference organisms in the presence of strain HR $1-2^{\mathrm{T}}$, antibiotic substances were not produced under the conditions employed in this experiment.

\section{Phylogenetic analysis}

The almost complete $16 \mathrm{~S}$ rDNA sequence, comprising 1462 nucleotides [94.8\% of the E. coli sequence (Brosius et al., 1978)] was determined for strain HR1$2^{\mathrm{T}}$. Similarity values were calculated for this strain compared to a representative selection of actinomycete species (not shown). Strain HR $1-2^{\mathrm{T}}$ was found to be more than $95 \%$ similar to members of the family Micromonosporaceae, the range in which members of the genera of this family are related among themselves (Koch et al., 1996a, b). Of the species of the Micromonosporaceae, M. olivasterospora $(98.0 \%)$, S. yamanashiensis $(97.4 \%)$ and Catenuloplanes japonicus (97.3\%; Yokota et al., 1993) showed the highest 16S rDNA similarity values to strain HR $1-2^{\mathrm{T}}$. The membership of strain HR $1-2^{\mathrm{T}}$ in the family Micromonosporaceae is also supported by the presence of an almost complete set of family-specific signature oligonucleotides (Stackebrandt et al., 1997) in its 16S rDNA sequence. The only deviation is the occurrence of an A-U pair at positions 1133-1141. All other members of the family exhibit a $\mathrm{G}-\mathrm{C}$ pair at these positions, therefore, this signature is not family-specific and should be excluded from the list of signatures. Screening the $16 \mathrm{~S}$ rDNA sequence of strain HR $1-2^{\mathrm{T}}$ for the presence of genus-specific signatures revealed a high similarity with members of the genus Micromonospora (11 of 12 common signatures; Koch et al., 


\section{H. Rheims and others}
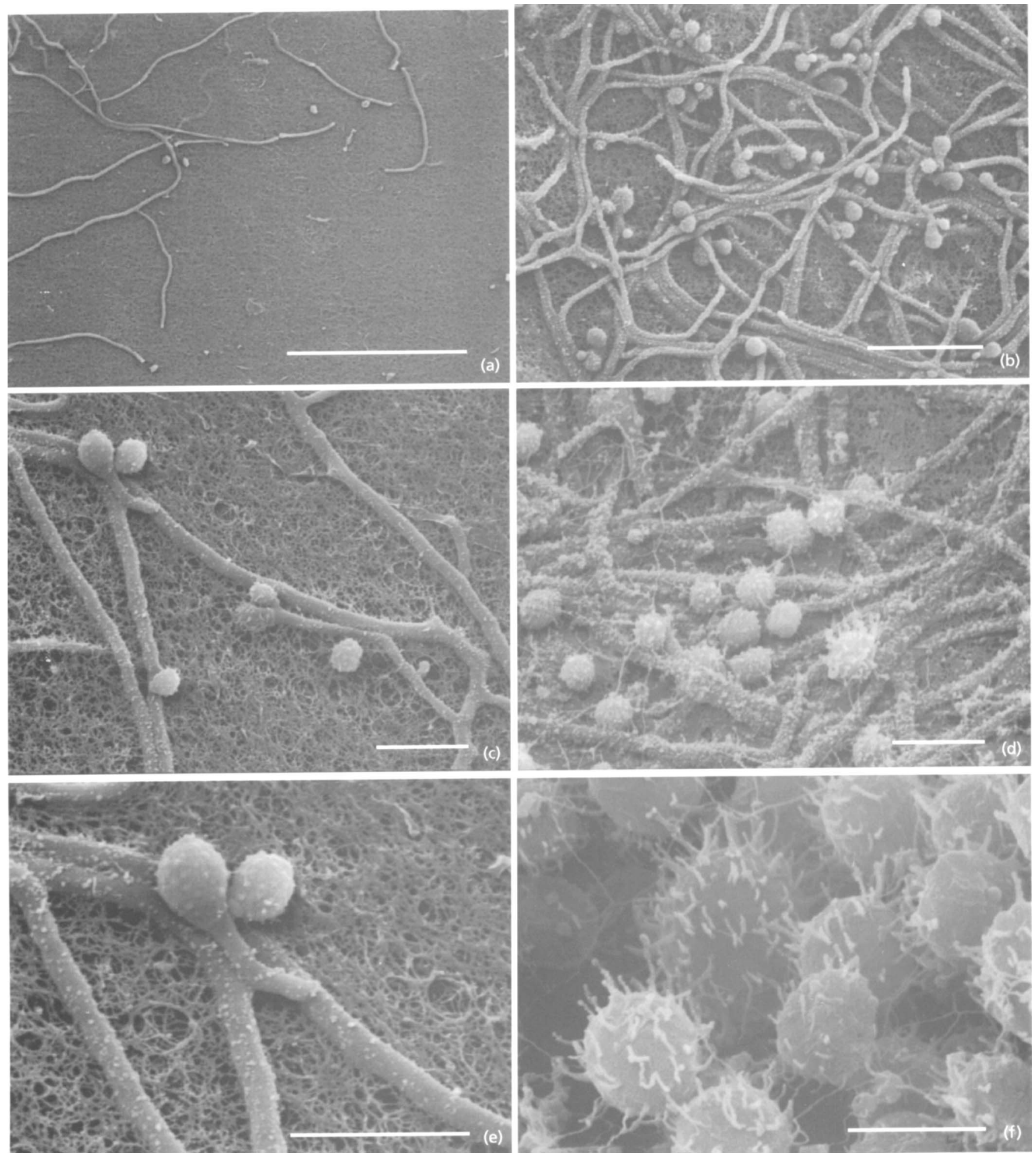

Fig. 1. Scanning electron microscopic images of isolate HR1-2 ${ }^{\top}$. (a) Young mycelium with smooth surface, partially grown into the agar surface; bar, $20 \mu \mathrm{m}$. (b) Overview of older mycelium, spores are already formed, parts of the mycelium show granulous structures on the surface; bar, $5 \mu \mathrm{m}$. (c) Mycelium with warty spores (overview); bar, $2 \mu \mathrm{m}$. (d) Old mycelium with spores; the mycelial surface developed a granular surface; bar, $2 \mu \mathrm{m}$. (e) Young spores in detail; bar, $2 \mu \mathrm{m}$. (f) Old spores in detail; the spore surface has become hairy; bar, $1 \mu \mathrm{m}$. 
Table 1. Physiological properties of strain $H R 1-2^{\top}$ and related organisms

,++ Good utilization; + , normal utilization; \pm , poor utilization; - , no utilization; $\mathrm{P}$, positive: N, negative; ND, not determined.

\begin{tabular}{|c|c|c|c|}
\hline Characteristic & Strain HR1-2 ${ }^{\mathrm{T}}$ & $\begin{array}{l}\text { Micromonospora } \\
\text { olivasterospora* }\end{array}$ & $\begin{array}{c}\text { Spirilliplanes } \\
\text { yamanashiensis } \dagger\end{array}$ \\
\hline \multicolumn{4}{|l|}{ Utilization as carbon source: } \\
\hline D-Xylose & ++ & ++ & + \\
\hline D-Ribose & - & ++ & ND \\
\hline D-Fructose & - & ++ & - \\
\hline D-Glucose & ++ & ++ & $+t$ \\
\hline D-Galactose & + & ++ & ND \\
\hline D-Mannose & \pm & ++ & ND \\
\hline Maltose & + & ++ & ND \\
\hline Sucrose & + & ++ & + \\
\hline$\alpha$-Trehalose & + & ++ & ND \\
\hline D-Arabinose & ++ & - & \pm \\
\hline L-Rhamnose & - & - & ++ \\
\hline L-Sorbose & - & - & ND \\
\hline Lactose & - & - & ND \\
\hline$\alpha$-Melibiose & - & - & ND \\
\hline Melezitose & - & - & ND \\
\hline Raffinose & - & - & + \\
\hline Glycerol & - & - & ND \\
\hline Dulcitol & - & - & - \\
\hline myo-Inositol & - & - & ND \\
\hline Sorbitol & - & - & ND \\
\hline Mannitol & - & - & ++ \\
\hline Salicin & + & - & ND \\
\hline \multicolumn{4}{|l|}{ Utilization as nitrogen source: } \\
\hline L-Serine & + & ++ & ND \\
\hline L-Aspartic acid & + & ++ & ND \\
\hline L-Glutamic acid & + & ++ & ND \\
\hline L-Histidine & + & ++ & ND \\
\hline L-Arginine & + & ++ & ND \\
\hline L-Alanine & \pm & - & ND \\
\hline L-Valine & \pm & - & ND \\
\hline L-Methionine & - & - & ND \\
\hline L-Phenylalanine & + & - & ND \\
\hline L-Tryptophan & - & - & ND \\
\hline Gelatin liquefaction & $\mathrm{P}$ & Weak P & $\mathrm{P}$ \\
\hline Peptonization of milk & $\mathrm{P}$ & $\mathrm{P}$ & $\mathrm{N}$ \\
\hline Starch hydrolysis & $P$ & $\mathrm{P}$ & $\mathrm{P}$ \\
\hline Nitrite produced from nitrate & $\mathrm{N}$ & $\mathrm{P}$ & $\mathrm{N}$ \\
\hline Cellulose decompositon & $\mathrm{N}$ & Weak P & $\mathrm{N}$ \\
\hline
\end{tabular}

* According to Kawamoto et al. (1983).

$\uparrow$ According to Tamura et al. (1997).

1996a). The only deviation is a $\mathrm{C}$ residue at position 998, which is either a $\mathrm{U}$ or a $\mathrm{G}$ residue in members of the other genera. However, the $\mathrm{C}$ residue at this position is also present in the closest phylogenetic neighbours, $C$. japonicus, $S$. yamanashiensis and $M$. olivasterospora (see below). Strain HR $1-2^{\mathrm{T}}$ exhibits a unique stretch of nucleotides between positions 1132 and 1142 (E. coli numbering), which contains a $3 \mathrm{bp}$ helical region (pos. 1132-1134/1140-1142) and a loop region (pos. 1135-1139), 5' CAAUUCGGUUG 3' (the loop region is underlined), which can be considered to be the $16 \mathrm{~S}$ rDNA signature for this strain.

Phylogenetic analysis of the $16 \mathrm{~S}$ rDNA sequence of strain HR $1-2^{\mathrm{T}}$ and members of the family Micromonosporaceae indicated that irrespective of the number and selection of reference organisms chosen, strain HR $1-2^{\mathrm{T}}$ formed an individual subline of descent within 


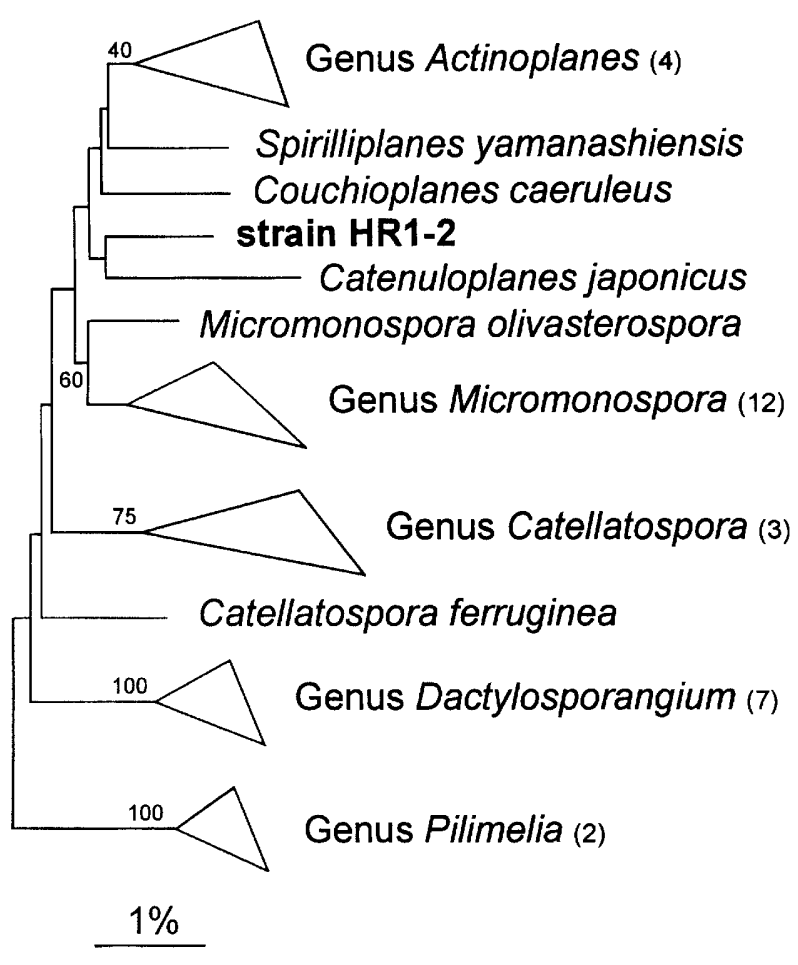

Fig. 2. Phylogenetic tree showing the position of isolate HR $1-2^{\top}$ within the family Micromonosporaceae, based upon 165 rDNA analysis. $M$. olivasterospora (DSM $43868^{\mathrm{T}}$ ) is shown as an individual lineage as this strain was found to be more closely related to strain $\mathrm{HR} 1-2^{\top}$ than other strains of the genus Micromonospora. The number of species of the different genera taken into account is given in parentheses. The sequence of Streptomyces ambofaciens served as an outgroup sequence. Numbers within the dendrogram indicate the percentages of occurrence of the branching order in 500 bootstrapped trees. The bar represents 1 nucleotide substitution per 100 nucleotides.

the family (Fig. 2). The branching point of this line, as well as those of its phylogenetically closest neighbours, members of Actinoplanes, Catenuloplanes, Couchioplanes, Micromonospora and Spirilliplanes, changed their position in the 16S rDNA dendrogram without, however, changing the genus affiliation of the species. Low bootstrap values found for the branching points of deeply branching lineages are yet another indication of the uncertainty about the order in which these lineages emerged during evolution. Despite strain HR $1-2^{\mathrm{T}}$ showing the highest $16 \mathrm{~S}$ rDNA similarity percentage with $M$. olivasterospora, the branching point of strain HR $1-2^{\mathrm{T}}$ indicates that this isolate is not a member of the genus Micromonospora. Similar high similarity values were also found for $S$. yamanashiensis and $M$. olivasterospora $(97.9 \%)$ and between the latter species and C. japonicus $(97 \cdot 3 \%)$.

\section{DNA base composition and DNA-DNA relatedness}

The $\mathrm{G}+\mathrm{C}$ content of the DNA of isolate HR $1-2^{\mathrm{T}}$ was $70 \mathrm{~mol} \%$. To verify the species status of strain HR1$2^{\mathrm{T}}$, DNA-DNA hybridization was carried out between this strain and its two phylogenetically closest relatives, $M$. olivasterospora and $S$. yamanashiensis. The level of DNA-DNA relatedness between isolate HR $1-2^{\mathrm{T}}$ and $M$. olivasterospora and $S$. yamanashiensis was 41.4 and $40.7 \%$, respectively. M. olivasterospora and S. yamanashiensis showed $30.8 \%$ DNA similarity. These values exclude the affiliation of strain HR $1-2^{\mathrm{T}}$ to either species (Wayne et al., 1987; Stackebrandt \& Goebel, 1994) and confirms the isolated phylogenetic position as indicated in Fig. 2.

\section{Chemotaxonomic properties}

The decision whether or not strain HR $1-2^{\mathrm{T}}$ constitutes the nucleus of a new genus or whether it should be affiliated to one of the described genera of the family should not be done solely on the basis of the phylogenetic analysis but should include analysis of chemotaxonomic data. The application of this combination of data, together with morphological properties, has been the most successful approach in the delineation of actinomycete genera during the past 20 years (Embley \& Stackebrandt, 1994).

Fatty acid profiles. The fatty acid profile of isolate HR $1-2^{\mathrm{T}}$ (Table 2) is characterized by the predominance of iso- $\mathrm{C}_{15: 0}$, followed by iso- $\mathrm{C}_{16: 0}$ and anteiso$\mathrm{C}_{17: 0}$. The predominance of iso- $\mathrm{C}_{15: 0}$ and iso- $\mathrm{C}_{17: 0}$ fatty acids over anteiso $C_{15: 0}$ and anteiso- $C_{17: 0}$ fatty acids, the occurrence of significant amounts of unsaturated fatty acids and the absence of 10-methyland 2-OH-fatty acids matches the diagnostic fatty acid type $2 \mathrm{~d}$ (Kroppenstedt, 1985). A different composition is found in the phylogenetic neighbours of strain HR1$2^{\mathrm{T}}$ such as $S$. yamanashiensis, $M$. olivasterospora and C. japonicus (Table 3).

Peptidoglycan. The directly cross-linked peptidoglycan of isolate HR $1-2^{\mathrm{T}}$ contained glycine in position 1 of the peptide subunit and meso-diaminopimelic acid as the diagnostic amino acid. Isolate HR $1-2^{\mathrm{T}}$ therefore represents peptidoglycan type $\mathrm{Al} \gamma^{\prime}$ as described by Schleifer \& Seidel (1985). This type is represented in all members of the family. The acyl type of muramic acid was glycolyl.

Whole-cell sugars. Characteristic whole-cell sugars are xylose, mannose and minor amounts of ribose, arabinose is absent. An additional sugar of unknown composition was also present. S. yamanashiensis and $C$. japonicus also lack arabinose, while the remaining members of the family contain this sugar in whole cells (Table 3).

Isoprenoid quinones. Isoprenoid quinones were $\mathrm{MK}$ $9\left(\mathrm{H}_{4}\right)$, MK-9 $\left(\mathrm{H}_{6}\right)$, MK-10 $\left(\mathrm{H}_{4}\right)$ and MK-9 $\left(\mathrm{H}_{2}\right)$ at a peak area ratio of $77: 7: 5: 4$. This pattern is common among species of the family.

Polar lipids. The polar lipid pattern was type II (Lechevalier et al., 1977), phosphatidylethanolamine, diphosphatidylglycerol, phosphatidylinositol mannosides, consisting of phosphatidylserine and an un- 
Table 2. Chemotaxonomic characteristics of strain $H R 1-2^{\top}$ and related organisms

Values less than $1 \%$ not shown. Abbreviations: $\mathrm{i}$, iso; ai, anteiso; $\mathrm{A}_{2} \mathrm{pm}$, diaminopimelic acid;

Ara, arabinose; Gal, galactose; Glc, glucose; Man, mannose; Xyl, xylose; 3-O-Man, 3-Omethylmannose; PE, phosphatidylethanolamine; DPG, diphosphatidylglycerol; PIM, phosphatidylinositol mannoside; PSer, phosphatidylserine, PI, phosphatidylinositol.

\begin{tabular}{|c|c|c|c|}
\hline Characteristic & $\begin{array}{c}\text { Strain } \\
\text { HR1-2 }^{\mathrm{T}}\end{array}$ & $\begin{array}{c}\text { Micromonospora } \\
\text { olivasterospora* }\end{array}$ & $\begin{array}{c}\text { Spirilliplanes } \\
\text { yamanashiensis }\end{array}$ \\
\hline \multicolumn{4}{|l|}{ Cellular fatty acids } \\
\hline $\mathrm{i}-\mathrm{C}_{11: 0}$ & & $1 \cdot 6$ & $2 \cdot 7$ \\
\hline $\mathrm{i}-\mathrm{C}_{1 ;: 0}$ & $31 \cdot 1$ & $21 \cdot 2$ & $12 \cdot 9$ \\
\hline ai- $C_{15: 0}$ & $2 \cdot 2$ & $2 \cdot 9$ & $14 \cdot 6$ \\
\hline$C_{15: 0}$ & $1 \cdot 0$ & & $4 \cdot 8$ \\
\hline $\mathrm{i}-\mathrm{C}_{1 \mathrm{1} \cdot 0}$ & $18 \cdot 6$ & $29 \cdot 9$ & $12 \cdot 9$ \\
\hline $\mathrm{i}-\mathrm{C}_{16: 1}$ & & $7 \cdot 0$ & \\
\hline$C_{16: 0}$ & $1 \cdot 0$ & & $2 \cdot 6$ \\
\hline $\mathrm{C}_{16: 1}$ & $1 \cdot 0$ & $1 \cdot 7$ & $1 \cdot 5$ \\
\hline $\mathrm{i}-\mathrm{C}_{17: 0}$ & $8 \cdot 3$ & $3 \cdot 5$ & $1 \cdot 2$ \\
\hline ai-C $C_{12: 4}$ & $16 \cdot 0$ & $5 \cdot 8$ & $5 \cdot 3$ \\
\hline $\mathrm{i}-\mathrm{C}_{1 ;: 1}$ & $4 \cdot 0$ & 6.9 & \\
\hline ai- $C_{17: 1}^{11}$ & & $3 \cdot 1$ & \\
\hline $\mathrm{C}_{17: 0}$ & $2 \cdot 9$ & & $15 \cdot 0$ \\
\hline $\mathrm{C}_{1 i: 1}$ & & & $17 \cdot 5$ \\
\hline$i-C_{1 x: 0}$ & $4 \cdot 4$ & $1 \cdot 6$ & \\
\hline $\mathrm{C}_{18: 0}$ & & & $3 \cdot 3$ \\
\hline $\mathrm{i}-\mathrm{C}_{1 \times: 1}$ & & $1 \cdot 1$ & \\
\hline $\mathrm{C}_{18: 1}$ & $1 \cdot 8$ & $1 \cdot 6$ & $2 \cdot 2$ \\
\hline $\mathrm{C}_{19: 0}$ & & & $2 \cdot 0$ \\
\hline Unidentified & & & $1 \cdot 5$ \\
\hline $\begin{array}{l}\text { Sugar composition of } \\
\text { whole cells }\end{array}$ & $\begin{array}{c}\text { Man, Xyl, } 1 \\
\text { unknown }\end{array}$ & Xyl, Ara, Glc & $\begin{array}{c}\text { 3-O-Man, Man, } \\
\text { Gal, Xyl, Glc }\end{array}$ \\
\hline Cell wall chemotype & II & II & II \\
\hline Major menaquinones & MK-9 $\left(\mathrm{H}_{4}\right)$ & $\begin{array}{l}\left.\text { MK-10( } \mathrm{H}_{4}\right) \\
\left.\text { MK-9(- } \mathrm{H}_{4}\right)\end{array}$ & MK-10(H $)$ \\
\hline Polar lipids & $\begin{array}{l}\text { PE, DPG, } \\
\text { PIM, PSer, } \\
1 \text { unknown }\end{array}$ & PE, DPG, PIM & PI, PE \\
\hline Peptidoglycan & meso- $\mathrm{A}_{2} \mathrm{pm}$ & $\begin{array}{c}\text { meso-, hydroxy- } \\
\mathrm{A}_{2} \mathrm{pm}\end{array}$ & meso- $\mathrm{A}_{2} \mathrm{pm}$ \\
\hline
\end{tabular}

* According to Kawamoto et al. (1983) and our own investigations.

$\dagger$ According to Tamura et al. (1997).

$\$$ According to Lechevalier \& Lechevalier (1970).

known phospholipid, a pattern common among species of the family.

On the basis of the combination of morphological, chemotaxonomic, physiological and phylogenetic factors, strain HR $1-2^{\mathrm{T}}$ is a member of the family Micromonosporaceae but can be readily distinguished from the genera presently affiliated to this family (Table 3). Therefore, we propose that strain HR $1-2^{\mathrm{T}}$ $\left(=\mathrm{DSM} 44337^{\mathrm{T}}\right.$ ) be classified as the type strain of the type species of the new genus, designated Verrucosispora gen. nov. as Verrucosispora gifhornensis sp. nov.

\section{Description of Verrucosispora gen. nov.}

Verrucosispora (Ver.ru'co.si.spo.ra. L. fem. n. verruca wart; Gr. n. spora a seed; M.L. fem. n. Verrucosispora an organism with warty spores).

Gram-positive, non-acid fast, aerobic organism with branching hyphae. Well-developed septate mycelium averaging $0.4 \mu \mathrm{m}$ in diameter. Non-motile spores borne singly, sessile, or on short or long sporophores. Warty spore surface changes to a hairy appearance with increasing age. Aerial mycelium absent. The peptide side-chain of peptidoglycan contains mesodiaminopimelic acid, glycine, alanine and glutamic 
Table 3. Differential characteristics of the genus Verrucosispora and related genera

,+ Present; -, absent; ND, not determined. Abbreviations: Man, mannose; Xyl, xylose; Gal, galactose; Ara, arabinose.

\begin{tabular}{|c|c|c|c|c|c|c|c|c|}
\hline Genus & $\begin{array}{c}\text { DNA G }+ \text { C } \\
\text { content }(\mathrm{mol} \%)\end{array}$ & $\begin{array}{l}\text { Motility of } \\
\text { spores }\end{array}$ & $\begin{array}{l}\text { Sporangium } \\
\text { formation }\end{array}$ & $\begin{array}{c}\text { Fatty acid } \\
\text { type }^{*}\end{array}$ & $\begin{array}{c}\text { Cell wall } \\
\text { typet }\end{array}$ & Major menaquinone(s) & $\begin{array}{c}\text { Phospholipid } \\
\text { type }\end{array}$ & $\begin{array}{c}\text { Characteristic sugar(s) } \\
\text { in whole cells }\end{array}$ \\
\hline Verrucosispora & 70 & - & - & $2 b$ & II & MK-9(- $\left.\mathrm{H}_{4}\right)$ & PII & Man, Xyl \\
\hline Spirilliplanes & 69 & + & - & $2 \mathrm{~d}$ & II & MK-10( $\left.\mathbf{H}_{4}\right)$ & PII & Xyl, Gal \\
\hline Actinoplanes.s & $72-73$ & + & + & $2 \mathrm{~d}$ & II & MK-9(- $\left.\mathrm{H}_{4}\right), \mathrm{MK}-10\left(\mathrm{H}_{4}\right)$ & PII & Ara, $X y l$ \\
\hline Dactylosporangium & $72-73$ & + & + & $3 b$ & II & MK-9(- $\left.\mathrm{H}_{4}, \mathrm{H}_{6}, \mathrm{H}_{8}\right)$ & PII & Ara, Xyl \\
\hline Pilimelia & $\mathrm{ND}$ & + & + & $2 \mathrm{~d}$ & II & MK-9( $\left.\mathrm{H}_{2}, \mathrm{H}_{4}\right)$ & PII & Ara, $\mathrm{Xyl}$ \\
\hline Micromonospora & $71-73$ & - & - & $3 \mathrm{~b}$ & II & MK-10( $\left.\mathrm{H}_{4}, \mathrm{H}_{6}\right)$, MK-9(- $\left.\mathrm{H}_{4}, \mathrm{H}_{6}\right)$ & PII & Ara, Xyl \\
\hline Catenuloplanes & $71-73$ & + & - & $2 \mathrm{c}$ & VI & MK-9( $\left.\mathrm{H}_{3}\right)$, MK-10( $\left.\mathrm{H}_{8}\right)$ & PIII & $\mathrm{Xyl}$ \\
\hline Couchioplanes & $70-72$ & + & - & $2 \mathrm{c}$ & VI & MK- $9\left(\mathrm{H}_{4}\right)$ & PII & Xyl. Ara. Gal \\
\hline Catellatospora & $71-72$ & - & - & sD & II & MK-10( $\left.\mathrm{H}_{8}, \mathrm{H}_{6}\right)$, MK-9 $\left(\mathrm{H}_{4}, \mathrm{H}_{6}\right)$ & PII & Ara, Xyl \\
\hline Glycomyes & $71-73$ & - & - & $2 \mathrm{c}$ & II & 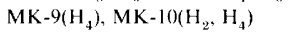 & PI & Ara, $X y l$ \\
\hline
\end{tabular}

* According to the classification of Kroppenstedt (1985).

+ According to the classification of Lechevalier \& Lechevalier (1970).

$\ddagger$ According to the classification of Lechevalier et al. (1977).

acid. The peptide side-chains are directly cross-linked (type $\mathrm{A} 1 \gamma^{\prime}$ ). The acyl type of the muramyl residue is glycolyl. Mannose, xylose and minor amounts of ribose are present in whole-cell hydrolysates. Characteristic phospholipids are phosphatidylethanolamine, diphosphatidylglycerol, phosphatidylinositol mannosides, phosphatidylserine. The major menaquinone is MK-9 $\left(\mathrm{H}_{4}\right)$, with minor amounts of MK-9( $\left.\mathrm{H}_{6}\right)$, MK$10\left(\mathrm{H}_{4}\right)$ and MK-9 $\left(\mathrm{H}_{2}\right)$. Major fatty acids $(>15 \%$ of total) are iso- $\mathrm{C}_{15: 0}$, iso- $\mathrm{C}_{16: 0}$ and anteiso- $\mathrm{C}_{17: 0}$, with minor amounts $(>4$ to $<15 \%)$ of iso- $\mathrm{C}_{17: 0}$, iso- $\mathrm{C}_{17: 1}$ and iso- $\mathrm{C}_{18: 0}$. Strictly aerobic. Chemo-organotroph. Good growth occurs at temperatures between 30 and $40{ }^{\circ} \mathrm{C}$. The $\mathrm{G}+\mathrm{C}$ content of the DNA is $70 \mathrm{~mol} \%$ (determined by HPLC). A member of the family Micromonosporaceae. Type species: Verrucosispora gifhornensis.

\section{Description of Verrucosispora gifhornensis sp. nov.}

Verrucosispora gifhornensis (gif'horn.en.sis. L. -ensis ending to denote a locality; M.L. fem. n. gifhornensis referring to the city of Gifhorn, adjacent to the peat bog from which the organism was isolated).

The description of morphological, chemotaxonomic and general characteristics are as described for the genus. An orange pigment is produced on all media tested, including ISP media 1, 2, 4, 5, 6 and 7. Gelatin liquefaction and peptonization of milk are positive. Hydrolyses starch. Nitrite not produced from nitrate. Cellulose decomposition is negative. D-Xylose, Dglucose, D-galactose, maltose, sucrose, D-arabinose and $\alpha$-trehalose are utilized; D-ribose, D-fructose, Lrhamnose, L-sorbose, lactose, $\alpha$-melibiose, melizitose, raffinose, glycerol, dulcitol, myo-inositol and salicin are not utilized. L-Serine, L-aspartic acid, L-glutamic acid, L-histidine, L-arginine and L-phenylalanine are used as nitrogen source. Highly sensitive to a wide range of antibiotics. A stretch of the 16S rDNA sequence between positions 1132-1142 (5' CAAUU-
CGGUUG $3^{\prime}$ ) is the molecular signature of the species. The $\mathrm{G}+\mathrm{C}$ content of the DNA is $70 \mathrm{~mol} \%$ (determined by HPLC). The type strain is HR $1-2^{\mathrm{T}}$ (DSM $\left.44337^{\mathrm{T}}\right)$.

\section{ACKNOWLEDGEMENTS}

We wish to thank Jutta Burghardt for carrying out the determination of the $\mathrm{G}+\mathrm{C}$ mol $\%$ content for isolate HR 1 $2^{\mathrm{T}}$ and her excellent technical assistance in carrying out the DNA-DNA hybridization studies. Anja Frühling, Gabriele Pötter-Reinemann and Bettina Henze are thanked for their technical advice regarding parts of the physiological tests. H. R. was supported by a grant from the German Research Council to E.S. (DFG-Sta 184/13-1).

\section{REFERENCES}

Anonymous (1991). Methoden zur Empfindlichkeitsprüfung von bakteriellen Krankheitserregern (außer Mykobakterien) gegen Chemotherapeutika, DIN 58940, Deutsches Institut für Normung e. V., Berlin, Beuth Verlag GmbH, 10772 Berlin.

Brosius, J., Palmer, M. L., Kennedy, P. J. \& Noller, H. F. (1978). Complete nucleotide sequence of the 16S ribosomal RNA gene from Escherichia coli. Proc Natl Acad Sci USA 75, 4801-4805.

Cashion, P., Holder-Franklin, M. A., McCully, J. \& Franklin, M. (1977). A rapid method for the base ratio determination of bacterial DNA. Anal Biochem 81, 461-466.

Collins, M. D. \& Jones, D. (1980). Lipids in the classification and identification of coryneform bacteria containing peptidoglycans based on 2,4-diaminobutyric acid. $J$ Appl Bacteriol 48, 459-470.

Collins, M. D., Pirouz, T., Goodfellow, M. \& Minnikin, D. E. (1977). Distribution of menaquinones in actinomycetes and corynebacteria. J Gen Microbiol 100, 221-230.

Collins, C. H., Lyne, P. M. \& Grange, J. M. (1989). Collins and Lyne's Microbiological Methods, 6th edn, pp. 52-83. London: Butterworth.

DeLey, J., Cattoir, H. \& Reynaerts, A. (1970). The quantitative measurement of DNA hybridization from renaturation rates. Eur J Biochem 12, 133-142.

DeSoete, G. (1983). A least squares algorithm for fitting additive trees to proximity data. Psychometrika 48, 621-626. 
Embley, T. M. \& Stackebrandt, E. (1994). The molecular phylogeny and systematics of the actinomycetes. Annu Rev Microbiol 48, 257-289.

Escara, J. F. \& Hutton, J. R. (1980). Thermal stability and renaturation of DNA in dimethylsulphoxide solutions: acceleration of renaturation rate. Biopolymers 19, 1315-1327.

Felsenstein, J. (1985). Confidence limits on phylogenies: an approach using the bootstrap. Evolution 39, 783-789.

Gerhardt, P., Murray, R. G. E., Costilow, R. N., Nester, E. W., Wood, W. A., Krieg, N. R. \& Phillips, R. B. (1981). Manual of Methods for General Bacteriology. Washington, DC: American Society for Microbiology.

Gordon, R. E., Haynes, W. C. \& Pang, C. H. (1973). The genus Bacillus. Agricultural Handbook 427. Washington, DC: US Department of Agriculture.

Groth, I., Schumann, P., Weiss, N., Martin, K. \& Rainey, F. A. (1996). Agrococcus jenensis gen. nov., sp. nov., a new genus of actinomycetes with diaminobutyric acid in the cell wall. Int $J$ Syst Bacteriol 46, 234-239.

Hayakawa, M. \& Nonomura, H. (1987). Humic acid-vitamin agar, a new medium for selective isolation of soil actinomycetes. $J$ Ferment Te'chnol 65, 501-509.

Huß, V. A. R., Festl, H. \& Schleifer, K. H. (1983). Studies on the spectrophotometric determination of DNA hybridization from renaturation rates. Syst Appl Microbiol 4, 184-192.

Jahnke, K.-D. (1992). BASIC computer program for evaluation of spectroscopic DNA renaturation data from GILFORD SYSTEM 2600 spectrophotometer on a PC/XT/AT type personal computer. J Microbiol Methods 15, 61-73.

Jukes, T. H. \& Cantor, C. R. (1969). Evolution of protein molecules. In Mammalian Protein Metabolism, pp. 21-132. Edited by H. N. Munro. New York: Academic Press.

Kawamoto, I., Yamamoto, M. \& Nara, T. (1983). Micromonospora olivasterospora sp. nov. Int J Syst Bacteriol 33, 107-112.

Koch, C., Kroppenstedt, R. M., Rainey, F. A. \& Stackebrandt, E. (1996a). 16S ribosomal DNA analysis of the genera Micromonospora. Actinoplanes, Catellatospora, Catenuloplanes, Couchioplanes, Dactylosporangium, and Pilimelia and emendation of the family Micromonosporaceae. Int J Syst Bacteriol 46, 765-768.

Koch, C., Kroppenstedt, R. M. \& Stackebrandt, E. (1996b). Intrageneric relationships of the actinomycete genus Micromonospora. Int J Syst Bacteriol 46, 383-387.

Kroppenstedt, R. M. (1985). Fatty acid and menaquinone analysis of actinomycetes and related organisms. In Chemical Methods in Bacterial Systematics, pp. 173-199. Edited by M. Goodfellow \& D. E. Minnikin. London: Academic Press.

Lechevalier, M. P. \& Lechevalier, H. A. (1970). Chemical composition as a criterion in the classification of aerobic actinomycetes. Int J Syst Bacteriol 20, 435-443.

Lechevalier, M. P., DeBievre, C. \& Lechevalier, H. A. (1977). Chemotaxonomy of aerobic actinomycetes: phospholipid composition. Biochem Syst Ecol 5, 249-260.

Maidak, B. L., Olsen, G. J., Larsen, N., Overbeck, R., McCaughey, M. J. \& Woese, C. R. (1997). The RDP (Ribosomal Database Project). Nucleic Acids Res 25, 109-111.

MacKenzie, S. L. (1987). Gas chromatographic analysis of amino acids as the $N$-heptafluorobutyryl isobutyl esters. $J$ Assoc Off Anal Chem 70, 151-160.
Mesbah, M., Premachandran, U. \& Whitman, W. B. (1989). Precise measurement of the $\mathrm{G}+\mathrm{C}$ content of deoxyribonucleic acid by high performance liquid chromatography. FEMS Microbiol Lett 25, 125-128.

Minnikin, D. E., Alshamaony, L. \& Goodfellow, M. (1975). Differentiation of Mycobacterium, Nocardia, and related taxa by thin-layer chromatographic analysis of whole-organism methanolysates. J Gen Microbiol 88, 200-204.

Minnikin, D. E., Collins, M. D. \& Goodfellow, M. (1979). Fatty acid and polar lipid composition in the classification of Cellulomonas, Oerskovia and related taxa. J Appl Bacteriol 47, 87-95.

Rainey, F. A., Ward-Rainey, N., Kroppenstedt, R. M. \& Stackebrandt, E. (1996). The genus Nocardiopsis represents a phylogenetically coherent taxon and a distinct actinomycete lineage: proposal of Nocardiopsaceae fam. nov. Int J Syst Bacteriol 46, 1088-1092.

Saddler, G. S., Tavecchia, P., Lociuro, S., Zanol, M., Colombo, L. \& Selva, E. (1991). Analysis of madurose and other actinomycete whole cell sugars by gas chromatography. $J$ Microbiol Methods 14, 185-191.

Schleifer, K. H. \& Kandler, O. (1972). Peptidoglycan types of bacterial cell walls and their taxonomic implications. Bacteriol Rev 36, 407-477.

Schleifer, K. H. \& Seidel, P. H. (1985). Chemical composition and structure of murein. In Chemical Methods in Bacterial Systematics, pp. 201-219. Edited by M. Goodfellow \& D. E. Minnikin. London: Academic Press.

Shirling, E. B. \& Gottlieb, D. (1966). Methods for characterization of Streptomyces species. Int J Syst Bacteriol 16, 313-340.

Stackebrandt, E. \& Goebel, B. (1994). Taxonomic note: a place for DNA-DNA reassociation and $16 \mathrm{~S}$ rRNA sequence analysis in the present species definition in bacteriology. Int $J$ Syst Bacteriol 44, 846-849.

Stackebrandt, E., Rainey, F. A. \& Ward-Rainey, N. L. (1997). Proposal for a hierarchic classification system, Actinobacteria classis nov. Int J Syst Bacteriol 47, 479-491.

Stanier, R. Y., Palleroni, N. J. \& Doudoroff, M. (1966). The aerobic pseudomonads: a taxonomic study. $J$ Gen Microbiol 43, $159-271$

Stead, D. E., Sellwood, J. E., Wilson, J. \& Viney, I. (1992). Evaluation of a commercial identification system based on fatty acid profiles for rapid, accurate identification of plant pathogenic bacteria. $J$ Appl Bacteriol 72, 315-321.

Tamura, T., Hayakawa, M. \& Hatano, K. (1997). A new genus of the order Actinomycetales, Spirilliplanes gen. nov., with description of Spirilliplanes yamanashiensis sp. nov. Int J Syst Bacteriol 47, 97-102.

Uchida, K. \& Aida, K. (1984). An improved method for the glycolate test for simple identification of the acyl type of bacterial cell walls. $J$ Gen Appl Microbiol 30, 131-134.

Wayne, L. G., Brenner, D. G., Colwell, R. R. \& 9 other authors (1987). International Committee on Systematic Bacteriology. Report of the ad hoc committee on reconciliation of approaches to bacterial systematics. Int J Syst Bacteriol 37, 463-464.

Yokota, A., Tamura, T., Hasegawa, T. \& Huang, L. H. (1993). Catenuloplanes japonicus gen. nov., sp. nov., nom. rev., a new genus of the order Actinomycetales. Int $J$ Syst Bacteriol 43, $805-812$. 
